\title{
Isolation and characterization of plant and human pathogenic bacteria from green pepper (Capsicum annum L.) in Riyadh, Saudi Arabia
}

\author{
Samiah H. S. Al-Mijalli
}

Received: 30 December 2012/ Accepted: 12 April 2013/Published online: 14 August 2013

(C) The Author(s) 2013. This article is published with open access at Springerlink.com

\begin{abstract}
Forty-three bacterial isolates in five genera were recovered from naturally infected green pepper fruits (38 samples) showing dark brown, irregular-shaped splotches. The pathogenicity test was performed on healthy green pepper fruits and red colonies were from inoculated fruits showing the same symptoms and the infected area developed into soft rot. Their identification was based on phenotypic characters and sequence of the gene fragment coding 16S rRNA. Of 43 isolates, 10 showing splotches on green pepper fruits belonged to genus Serratia on the basis of phenotypic characters. One representative isolate of the genus Serratia has been identified by partial $16 \mathrm{~S}$ rRNA gene sequencing and phylogenetic analysis as belonging to the Serratia rubidaea and has the potential to cause spot on green pepper. Eleven phytopathogenic bacterial isolates were also obtained at the same time but did not induce any splotch symptoms on artificially infected green pepper. Five out of 11 bacterial isolates were identified as Ralstonia on the basis of biochemical tests. Partial sequencing of $16 \mathrm{~S}$ ribosomal gene of representative isolate revealed that the isolate is Ralstonia solanacearum. The six remaining isolates were related to Xanthomonas vesicatoria on the basis of biochemical tests. Twenty-two of opportunistic human pathogens were isolated at the same time and related to Proteus and Klebsiella. Opportunistic human pathogens did not produce any symptoms on artificially infected green pepper. One representative isolate for each genus was identified as Klebsiella oxytoca and Proteus mirabilis based on their partial 16S rRNA gene sequences. The virulence of the $S$. rubidaea, the causal agent of green
\end{abstract}

S. H. S. Al-Mijalli ( $₫)$

Biology Department, College of Sciences, Nora Bent

AbdulRahman University, Riyadh, Saudi Arabia

e-mail: dr.samiah10@hotmail.com; SHSM2000@live.com pepper fruits splotches was attributed to the production and secretion of a large variety of enzymes capable of degrading the complex polysaccharides of the plant cell wall and membrane constituents.

Keywords Green pepper - Pathogenic bacteria . Klebsiella oxytoca $\cdot$ Proteus mirabilis

\section{Introduction}

The role of fresh fruits and vegetables in nutrition and healthy diet is well recognized and in recent years, many countries have undertaken various initiatives to encourage consumers to eat more of these products. Fruits and vegetables supply much needed vitamins, minerals, and fibers. These play an important role in health through the prevention of heart disease, cancer, and diabetes. The health aspect together with increasing consumer demands for variety and availability, and the changing structure of global trade has led to an increase in trade of fruits and vegetables (Abd-Alla et al. 2011).

Agricultural products can be exposed to microbial contamination through a variety of sources. Although vegetables are good examples of minimally processed foods, there is a high risk of contamination. Since fruits and vegetables are produced in a natural environment, they are vulnerable to contamination by human pathogens. The increased consumption of fruits and vegetables may have unintended consequences with an increase in number of outbreaks. The majority of diseases associated with fresh fruits and vegetables are primarily those transmitted by the fecal-oral route, and therefore, are a result of contamination at some point in the process (De Roever 1998). Therefore good hygienic measures have to be taken during 
the production from farm to table. The world has seen significant changes in eating habits and consumption of fresh products is increasingly becoming important in the diet of many people, especially reflected in the increased demand for organically produced food. In the production and processing of fresh produce quality and hygiene are the most important criteria for the consumers. Such food products are often eaten raw and, if contaminated with pathogenic bacteria may represent a health hazard to consumers (Bruhn 1995).

Bacterial soft rot is a leading cause of postharvest losses of potatoes (Cappellini et al. 1984), tomatoes (Ceponis et al. 1986), peppers (Ceponis et al. 1987), lettuce (Ceponis et al. 1985), and other fresh fruits and vegetables in the marketplace. It is caused by a group of plant pathogens, harmless to humans, that includes Erwinia carotovora, pectolytic Pseudomonas fluorescens and P. viridiflava (Lund 1983). Pectolytic breakdown of affected tissues results in softening, liquefaction, and exudates that can spread bacteria over commodities in bulk storage or display, contaminate food-handling equipment, and protect bacteria from the environment (Snowdon 1990; Wei et al. 1995).

Serratia species were frequently found associated with plants (Grimont et al. 1981). Serratia marcescens, S. liquefaciens, and S. rubidaea were found in 29,28 , and $11 \%$, respectively, of vegetable salads served in a hospital in Pittsburgh (Wright et al. 1976). S. rubidaea, first described by (Stapp 1940), is an epiphyte on plants. S. rubidaea has been isolated from coconuts of Ivory Coast bought in both France and California (Grimont et al. 1981). The relative frequency of $S$. rubidaea in clinical specimens is rare, and there are no data to suggest that the organism is of clinical significance, but clinical significance cannot be totally excluded because of its occurrence in clinical specimens (Farmer et al. 1985).

Sequences of the 16S rRNA gene are generally used as a framework for bacterial classification. Therefore, sequencing of this gene was used as a first identification tool (Garcia-Martınez et al. 2001). Extracellular enzymes have a number of potential roles in plant disease, including overcoming host defense responses, mobilization of plant cell walls for nutritional purposes, facilitation of movement of bacteria into and between vascular elements, and promotion of bacterial survival on plant material in the soil. Successful management of plant diseases relies on correct diagnosis. Therefore, investigations on pathogenic bacteria and bacterial diseases on the fresh vegetable and fruit plants are economically important. The overall objective of this study was to determine and characterize the bacterial isolates recovered from green pepper fruits spot collected from different vegetable markets and their ability to produce an array of extracellular enzymes capable of degrading the complex polysaccharides of the plant cell wall and membrane constituents.

\section{Materials and methods}

Sample collection

Naturally infected green pepper Capsicum annum L. spots were collected from different vegetable markets in Riyadh, Saudi Arabia. The collected samples (38) were kept in refrigerator until the time of isolation. They were analyzed within $20 \mathrm{~h}$ of sampling.

Bacteriological analysis

Green pepper fruits with spot symptoms were washed with sterilized distilled water, and then treated with $0.5 \%$ solution of hypochlorite (bleach) (Cotter et al. 1985) for 1-2 min to remove the contaminants, rinsed with sterile distilled water and cut into small bits with sterile scalpel. These pieces were immersed in sterilized saline buffer and vortexed strongly. A tenfold dilution series was prepared and $100 \mu \mathrm{l}$ each of diluted and the undiluted extract was spread (with three replications of each dilution) on yeast dextrose chalk (YDC) medium (Schaad 1988) consisting of $20.0 \mathrm{~g} / 1$ dextrose, $10.0 \mathrm{~g} / 1$ yeast extract, and $20.0 \mathrm{~g} / 1$ $\mathrm{CaCO}_{3}$ with $15.0 \mathrm{~g} / \mathrm{l}$ of agar in 11 of distilled water. YDC medium was autoclaved for $15 \mathrm{~min}$ at $121^{\circ} \mathrm{C}$.

Cultures were incubated for $3-5$ days at $30{ }^{\circ} \mathrm{C}$. Discrete colonies were re-streaked onto YDC plates for pure culture isolation. One colony of the purified presumptive pathogen from each sample was selected and maintained on YDC slants at $4{ }^{\circ} \mathrm{C}$ for further tests.

\section{Pathogenicity test}

Green pepper fruits were swabbed with $70 \%$ ethanol and washed in sterile water and stabbed with sterile syringe needles at three sites. Inoculations were made by deposition of $5 \mu \mathrm{l}$ of a bacterial suspension on the upper surface of green pepper fruits. Three fruits were used for each isolate. Inocula were prepared from 48 -h-old cultures on nutrient broth medium incubated at $30^{\circ} \mathrm{C}$. Bacterial cells were collected in saline phosphate buffer $(\mathrm{pH} 7)$ and adjusted to $10^{7} \mathrm{cfu} / \mathrm{ml}$ by turbidity measurement (A600). Inoculated green pepper fruits were kept in closed transparent boxes lined with moist blotting and incubated at $30{ }^{\circ} \mathrm{C}$. All fruits were assessed daily for 7 days to record disease symptoms. The causal agent was recovered from green pepper showing the same symptoms on YDC. All bacterial isolates were tested for their ability to produce any symptoms. 
Biochemical characterization of bacterial isolates

Bacteriological characteristics of the isolates were examined by using the methods to include: Gram stain, Ryu's test, colony color, oxidase reaction, arginine dihydrolase, nitrate reduction, utilization of carbohydrates, Levin formation, catalase test, gelatin hydrolysis, starch hydrolysis, esculin and Tween 20, as previously described by Bergey's Manual (Brenner et al. 2005).

\section{Sequencing of $16 \mathrm{~S}$ rRNA gene}

DNA was extracted by boiling a small amount of a pure culture plate colony in DNAse- and RNAse-free water (Invitrogen, Carlsbad, CA). For the sequencing of the partial 16S rRNA gene fragments polymerase chain reaction amplifications were performed with universal bacterial primers (Lane 1991) [27f (9-27) GAGTTTGATCM TGGCTCAG and 1492r (1492-1510) ACGGYTACCTT GTTACGACTT] in a total volume of $25 \mu \mathrm{l}$. The reaction mixture contained 2.5 $\mu \mathrm{l}$ PCR-buffer, $2.0 \mu \mathrm{l} \mathrm{MgCl}_{2}$ (25 mM), $2.5 \mu \mathrm{ldNTPs}(2 \mathrm{mM}), 0.5 \mu \mathrm{l}$ of each primer, $15.7 \mathrm{ml}$ RNAse- and DNAse-free water, $0.2 \mu \mathrm{l} \mathrm{BSA}$ (20 mg/ml), $0.1 \mu \mathrm{l}$ Taq polymerase $\left(5 \mathrm{U}^{-1} \mathrm{l}^{-1}\right.$ ) (all MBI Fermentas, St. Leon Rot), and $1 \mu$ of the DNA extract. The reaction was performed using an Eppendorf Ag 22331 Authorized Thermal Cycler (Hamburg, Germany) with an initial denaturation step at $95{ }^{\circ} \mathrm{C}$ for $3 \mathrm{~min}$, followed by 29 cycles of denaturation $\left(95{ }^{\circ} \mathrm{C}\right.$ for $45 \mathrm{~s}$ ), annealing $\left(57.3^{\circ} \mathrm{C}\right.$ for $20 \mathrm{~s}$ ) and extension $\left(72^{\circ} \mathrm{C}\right.$ for $\left.2 \mathrm{~min}\right)$. The PCR was completed with a terminal extension step for $4 \mathrm{~min}$ at $72{ }^{\circ} \mathrm{C}$. PCR products were purified (PCR Purification Kit250, QiaQuicks, Qiagen, Hilden) and quantified photometrically (Ultrospec 4000, Amersham Biosciences, Freiburg). Purified PCR products were cycle sequenced in both directions with the same forward and reverser primers using an Applied Biosystems 3730X-1 DNA Analyzer (Fast Smack Inc. Division DNA synthesis, Kanagawa, Japan). The sequence reads were edited and assembled using BioEdit version 7.0.4 (http://www.mbio.ncsu.edu/ BioEdit/bioedit.html) and clustalW version 1.83 (http:// clustalw.ddbj.nig.ac.jp/top-e.html). BLAST searches were done using the NCBI server at http://www.ncbi.nlm.nih. gov/blast/Blast.cgi. Phylogenetic tree derived from $16 \mathrm{~S}$ rRNA gene sequence was generated in comparison to $16 \mathrm{~S}$ rRNA gene sequences from seven different standard bacterial strains obtained from Genbank (Lane 1991). Gene sequences that had been determined were phylogenetically analyzed using the ARB software package (Sanger et al. 1977). New sequences not included in the used ARB database were added from public databases (http://www. ncbi.nlm.nih.gov/BLAST) using BLASTN search to assign the closed relatives. The ARB_Edit tool was used for automatic sequence alignment and checking and correcting the alignment afterwards. Neighbor-joining algorithms (Drancourt et al. 2000) were used for calculating the trees.

\section{Enzymes' production by Serratia rubidaea}

Serratia rubidaea isolate was screened for its ability to elaborate hydrolytic enzymes such as lipase enzyme, protease enzyme, polygalacturonase enzyme and alkaline phosphatase enzyme. Bacteria were grown in $50 \mathrm{ml}$ of liquid medium in an Erlenmeyer flask $(250 \mathrm{ml})$ containing (g/l): $\mathrm{MgSO}_{4} \cdot 7 \mathrm{H}_{2} \mathrm{O}$ 0.2, $\mathrm{K}_{2} \mathrm{HPO}_{4} \quad 2.0, \mathrm{KH}_{2} \mathrm{PO}_{4} 2$ and casein 10 (pH 8) (Chakraborty and Srinivasan 1993). The basal medium for lipase production consisted of $(\mathrm{g} / \mathrm{l})$ : bacteriological peptone 15.0, yeast extract 5.0, $\mathrm{NaCl} 2.0$, $\mathrm{MgSO}_{4} \quad 0.4, \mathrm{~K}_{2} \mathrm{HPO}_{4} \quad 0.3, \mathrm{KH}_{2} \mathrm{PO}_{4} \quad 0.3$, and olive oil $10.0 \mathrm{ml}$ for lipase induction (Baharum et al. 2003). The basal medium for pectinase production consisted of $(\mathrm{g} / \mathrm{l})$ : pectin 4, yeast extract $2, \mathrm{NH}_{4} \mathrm{Cl} 1, \mathrm{MgSO}_{4} 0.5$ (Gomes et al. 1992). Cultures were incubated in an orbital shaking incubator for $36 \mathrm{~h}$ at $150 \mathrm{rpm}$ and $37{ }^{\circ} \mathrm{C}$. The culture broth was then centrifuged at $8,000 \mathrm{rpm}$ [may be better in $g$ (relative centrifuge force)] to remove cells. The clear supernatant was collected for enzymes assay.

\section{Enzymes assay}

Protease activity was assayed by a modified method of Ohara-Nemoto et al. (1994). The reaction was initiated by addition of $1 \mathrm{ml}$ supernatant to $2 \mathrm{ml}$ of reaction mixture containing $2.7 \mathrm{mg}$ of casein per $\mathrm{ml}$ in $50 \mathrm{mmol}$ Tris- $\mathrm{HCl}$ ( $\mathrm{pH}$ 8.0) which had been prewarmed at $37^{\circ} \mathrm{C}$. After incubation at $37{ }^{\circ} \mathrm{C}$ for 1 hour, the reaction was stopped by addition of $0.5 \mathrm{ml}$ of $15 \%$ ice-cold trichloroacetic acid. The reaction mixture was held on ice for $15 \mathrm{~min}$ and then centrifuged; $5 \mathrm{ml}$ of sodium carbonate solution (500 $\mathrm{mmol}$ ) was added to the reaction mixture followed by $1 \mathrm{ml}$ of Folin and Ciocalteu's phenol reagent (dilute $10 \mathrm{ml}$ of Folin and Ciocalteu's phenol reagent, to $40 \mathrm{ml}$ with distilled water). The soluble peptide in the supernatant fraction was measured with tyrosine as the reference compound. The absorbance at $660 \mathrm{~nm}$ of the sample was measured using a spectrophotometer (UNICO UV-2100, USA). One unit of enzyme activity was defined as the amount of enzyme that releases $1 \mu \mathrm{g}$ of tyrosine per min under the assay conditions. Controls containing autoclaved enzymes instead of active enzymes were used. Lipase activity was measured by universal titrimetric method (Fadıloğlu and SÖylemez 1997).

Polygalacturonase was determined according to the method of Gomes et al. (1992). One unit of activity is defined as that amount of enzyme which catalyzes the 
release of $1 \mu \mathrm{mol}$ of reducing groups per min and expressed as $\mathrm{U} / \mathrm{ml}$.

Alkaline phosphatase of bacterial culture supernatant was determined by standard assay procedure using alkaline phosphatase kit (ELI Tech, SEPPIM S.A.S.-Zone industrielle-61500 SEES France). One alkaline phosphatase unit was defined as the amount of enzyme which liberates $1 \mu \mathrm{mol}$ of $p$-nitrophenol as a result of hydrolysis of p-nitrophenylphosphate (pNPP) in 1 min (Abd-Alla 1994).

Effects of temperature on enzyme production and stability

The effect of temperature on lipase, protease, polygalacturonase, and alkaline phosphatase enzymes production was determined by incubating the culture flasks with different temperature regimes $\left(10,20,30\right.$, and $\left.40{ }^{\circ} \mathrm{C}\right)$. For determining thermal stability, the enzyme was pre-incubated at different times ranging from 10 to $70 \mathrm{~min}$ at maximum temperature $\left(45^{\circ} \mathrm{C}\right)$ and residual activity was measured under standard assay conditions.

\section{Results}

\section{Bacterial isolates}

A total of 38 samples were randomly taken from different vegetable markets of Riyadh. Forty-three bacterial isolates were obtained from naturally green pepper spot fruits. Four different bacterial colonies were observed on YDC medium. These colonies were distinguished into one type of yellow, two types of white mucoid and one type red.

\section{Pathogenicity test}

The pathogenicity test was performed on healthy green pepper fruits and red colonies were re-isolated from inoculated fruits showing splotches. Symptoms appeared as dark brown, irregular-shaped splotches and the infected area developed into soft rot. The other bacterial isolates of yellow and white colonies did not show any spot symptoms on green pepper fruits.

Phenotypic and genotypic characterization of the bacterial isolates

Ten out of 43 bacterial isolates showing spot on green pepper fruits were further characterized using comprehensive range of phenotypic test (Table 1). The isolates might be belonging to the genus of Serratia on the basis of their phenotypic characterization. One representative isolate of the genus Serratia was subjected to the partial 16S rRNA gene sequences of 612 base pairs. The selected isolates had 16S rRNA gene sequence with $99 \%$ similarity to the closet sequence of $S$. rubidaea AB004751 in GenBank. Eleven phytopathogenic bacterial isolates were also recovered at the same time. Five out of eleven bacterial isolates were identified as Ralstonia on the basis of biochemical tests. One representative isolate was chosen for further identification using phylogenetic analysis of $16 \mathrm{~S}$ rRNA gene sequences as the gold standard. The partial 16S rRNA gene sequence of 630 base pairs of the representative isolate had a sequence with $99 \%$ similarity to Ralstonia solanacearum U28224. A phylogenetic tree was constructed from a multiple sequences alignment of 16S rRNA gene sequences (Fig. 1). The other six isolates were related to Xanthomonas vesicatoria on the basis of phenotypic characters.

Other 22 non-phytopathogenic bacterial isolates were recovered at the same time from green pepper fruits. Ten out of 22 belonged to the genus Klebsiella on the basis of biochemical activities. The $16 \mathrm{~S}$ rRNA gene sequence of $571 \mathrm{bp}$ of the representative isolate was aligned with other $16 \mathrm{~S}$ rRNA gene sequence using ARB software package to demonstrate the relatedness of the isolate to other major groups. Sequence from the analyzed isolate shared $98 \%$ similarity to known strain of Klebsiella oxytoca AB353048 in GenBank database as supported by phylogenetic tree. The twelve remaining isolates were subjected to varieties of biochemical tests to determine the phenotypic traits and enable their identification. Data presented in Table 1 demonstrated that the isolates clearly belong to the genus of Proteus. The phenotype-based identification was confirmed by phylogenetic analysis. Comparison between $16 \mathrm{~S}$ rRNA gene sequence of the chosen isolates of genus Proteus and 16S rRNA gene sequences of GenBank database was made by using BLASTN search analysis. Sequencing of $16 \mathrm{~S}$ rRNA genes of the chosen isolate had 16S rRNA gene with $99 \%$ nucleotides identity to that of Proteus mirabilis EF626945 available in GenBank database. The phylogenetic tree was inferred from 16S rRNA sequence data by the neighbor-joining method (Fig. 1). The tested analyzed isolate was identified as $P$. mirabilis belonging to the family Enterobacteriaceae.

\section{Effect of temperature on enzymes production}

Serratia rubidaea has the ability to produce the extracellular enzyme which was thought to play an important role in host infection. Lipase, protease, polygalacturonase and alkaline phosphatase enzymes were detected in $S$. rubidaea isolates. The optimum temperature for lipase production by S. rubidaea was $25^{\circ} \mathrm{C}$ (Table 2; Fig. 2). It is obvious from the results in Fig. 2 that $30{ }^{\circ} \mathrm{C}$ temperature was generally more favorable for protease production by $S$. rubidaea. The optimum temperature for polygalacturonase production by 
Table 1 Biochemical characterization test of bacterial genera isolated from green pepper fruits

\begin{tabular}{|c|c|c|c|c|c|}
\hline Characteristics & Group 1 & Group 2 & Group 3 & Group 4 & Group 5 \\
\hline Phenotypic classification & Serratia & Ralstonia & Xanthomonas & Klebsiella & Proteus \\
\hline Fluorescent on king's B & - & - & - & - & - \\
\hline Growth on cetrimide & - & - & - & - & - \\
\hline Gram's staining & - & - & - & - & - \\
\hline $\mathrm{KOH}$ solubility & + & + & + & + & + \\
\hline Cytochrome $\mathrm{C}$ oxidase & - & + & - & - & - \\
\hline Nitrate reductase & + & + & - & + & + \\
\hline Catalase test & + & + & + & + & + \\
\hline Gelatin hydrolysis & + & + & + & - & - \\
\hline Casein hydrolysis & + & + & + & - & - \\
\hline Starch hydrolysis & - & - & - & + & + \\
\hline Arginine dehydrogenase & - & - & - & + & - \\
\hline Urease test & - & + & - & - & + \\
\hline $\mathrm{H}_{2} \mathrm{~S}$ production & - & - & - & + & + \\
\hline Esculin test & + & + & + & + & - \\
\hline Voges-Proskauer & - & - & - & - & - \\
\hline \multicolumn{6}{|l|}{ Carbon source utilization } \\
\hline L-Arabinose & - & - & + & + & - \\
\hline D-Cellobiose & + & - & + & + & - \\
\hline D-Fructose & - & + & + & + & - \\
\hline Citrate & + & - & - & + & - \\
\hline D-Alanine & + & - & - & + & + \\
\hline D-Sorbitol & - & + & - & + & + \\
\hline D-Galactose & + & - & - & + & - \\
\hline Glycerol & + & + & + & - & + \\
\hline Glucose & + & - & + & + & + \\
\hline Lactose & + & - & - & + & + \\
\hline Maltose & + & + & + & + & - \\
\hline Mannitol & + & + & + & + & + \\
\hline Growth at $4{ }^{\circ} \mathrm{C}$ & - & - & - & - & - \\
\hline Growth at $37^{\circ} \mathrm{C}$ & + & + & + & + & + \\
\hline Growth at $41{ }^{\circ} \mathrm{C}$ & + & - & + & + & + \\
\hline
\end{tabular}

Symbols - and + meaning negative and positive

S. rubidaea was $40^{\circ} \mathrm{C}$. The results presented in Fig. 2 revealed that the highest production of alkaline phosphatase by $S$. rubidaea was achieved at $37^{\circ} \mathrm{C}$ (Fig. 2; Table 2).

Thermal stability of produced enzymes

Thermal stability was investigated by incubating the enzymes produced by $S$. rubidaea. Lipase enzyme of $S$. rubidaea exhibits the highest thermal stability with $87 \%$ of maximum activity remaining after $10 \mathrm{~min}$, but $50 \%$ of the initial activity retained at $45{ }^{\circ} \mathrm{C}$ for $40 \mathrm{~min}$ (Fig. 3). Protease enzyme of $S$. rubidaea exhibits the highest thermal stability with $94 \%$ of maximum activity remaining after $10 \mathrm{~min}$, but $87 \%$ of the initial activity retained at $45{ }^{\circ} \mathrm{C}$ for
40 min (Fig. 3). The optimum temperature for polygalacturonase produced by $S$. rubidaea was $40^{\circ} \mathrm{C}$. At $45^{\circ} \mathrm{C}$, polygalacturonase enzyme of $S$. rubidaea exhibits the highest thermal stability with $88 \%$ of maximum activity remaining after $10 \mathrm{~min}$, however, $69 \%$ of the initial activity retained for $40 \mathrm{~min}$. Alkaline phosphatase enzyme of $S$. rubidaea exhibits the highest thermal stability with $93 \%$ of maximum activity remaining after $10 \mathrm{~min}$, but $65 \%$ of the initial activity retained at $45{ }^{\circ} \mathrm{C}$ for $40 \mathrm{~min}$.

\section{Discussion}

Phenotypic and genotypic techniques were used for identification and allowed us to infer the phylogeny of 43 


\section{Bacillus Subtilis Z99104WL3}

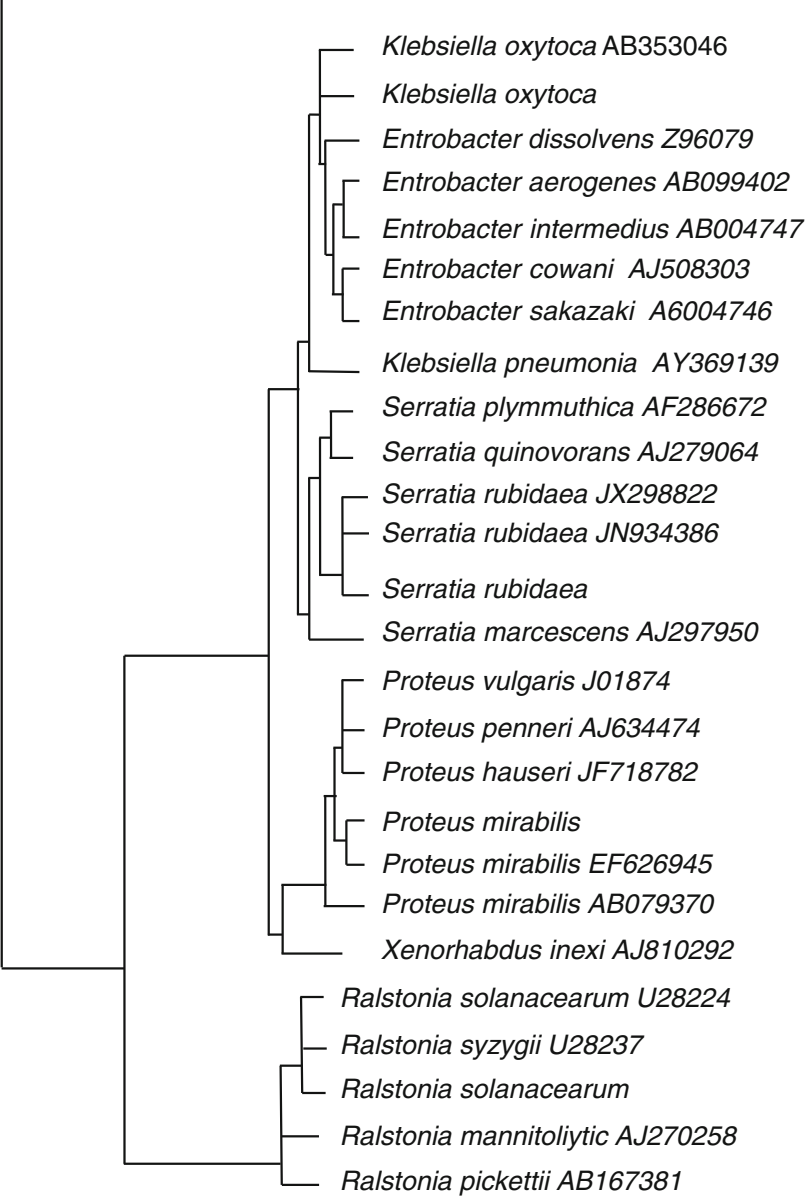

\subsection{1}

Fig. 1 Phylogenetic tree indicates the phylogenetic relationship of the isolated strains. Isolates are indicated in bold. A neighbor-joining tree was calculated using partial $16 \mathrm{~S}$ rRNA gene sequences $(1,362 \mathrm{bp})$ and a frequency filter included in the ARB software package. Bacillus subtilis was used as out-group. The scale bar indicates $10 \%$ estimated sequence difference. Accession numbers of the National Centre for Biotechnology Information (NCBI) database of each strain are given in brackets

bacterial isolates recovered from green pepper fruits, distributed along five genera ( $S$. rubidaea, X. vesicatoria, $R$. solanacearum, $K$. oxytoca and $P$. mirabilis) and comprising three bacterial families. Most pathogenic microbes must access the plant interior, either by penetrating the leaf or root surface directly or by entering through wounds or natural openings, such as stomata or leaf hydathodes (Kroupitski et al. 2009).

Plant pathogens may grow briefly on or in wounded tissue before advancing into healthy tissue. Injection of Salmonella into the tomato stem may introduce the pathogen into xylem, which has the principal role of transporting water and nutrients from the root to the extremities of the plant. Additionally, in the secondary xylem, the axial and ray parenchyma store nutrients and water (Blostein 1991) which sustain viability of plants and, possibly, promote survival of pathogenic bacteria. The presence of epiphyseal flora within tissue of fruits and vegetables through various pathways was reported by (Samish et al. 1962). By examining eight internal locations of green pepper fruits, they observed that bacteria are unevenly distributed in the fruit, and entry may be from the stem scar tissue through the core and into the endocarp. This study suggested that some epiphyseal flora might reach internal tissue of tomatoes through natural apertures because of their small size and motility. It may be that bacteria enter fruit tissue more readily in the early stages of fruit development, at a time when various channels are not yet covered by corky or waxy materials (Samish et al. 1962). Broken trichomes on young fruits represent another site of entry of microorganisms. Guo et al. 2001 reported that green pepper fruits, stem and flowers are possible sites at which Salmonella may attach and remain viable during fruit development, thus serving as routes or reservoirs for contaminating ripened fruit.

Klebsiella oxytoca is an opportunistic pathogen involved in nosocomial infections and antibiotic-associated diarrhea and hemorrhagic colitis (Högenauer et al. 2006; Gorkiewicz 2009). K. oxytoca can cause serious infections, bacteremia, and septic shocks in immunocompromised individuals (Al-Anazi et al. 2008). P. mirabilis is a common cause of urinary tract infection (Zunino et al. 2000). Recent studies have shown that enteric bacteria can colonize the interiors of plants (Tyler and Triplett 2008; Berg et al. 2005). Endophytic colonization was shown to result from root infection or contamination of seeds (Tyler and Triplett 2008). The extent of endophytic colonization is
Table 2 Effect of temperature on enzymes production of Serratia rubidaea lipase enzyme, protease enzyme, polygalacturonase enzyme, and alkaline phosphatase enzyme

Data expressed as $\mathrm{U} / \mathrm{mg}$ protein

\begin{tabular}{lrlll}
\hline Temperature & Lipase & Protease & Polygalacturonase & Phosphatase \\
\hline 10 & 550 & 0.026 & 750 & 0.15 \\
25 & 3,320 & 0.187 & 2,500 & 1.8 \\
30 & 1,600 & 0.23 & 2,500 & 4.2 \\
37 & 1,265 & 0.15 & 3,900 & 2.5 \\
40 & 600 & 0.075 & 4,500 & 0.8 \\
45 & 550 & 0.055 & 1,500 & 0.32 \\
\hline
\end{tabular}


Fig. 2 Effect of temperature on enzymes production of Serratia rubidaea. a Lipase enzyme, b protease enzyme,

c polygalacturonase enzyme, d alkaline phosphatase enzyme
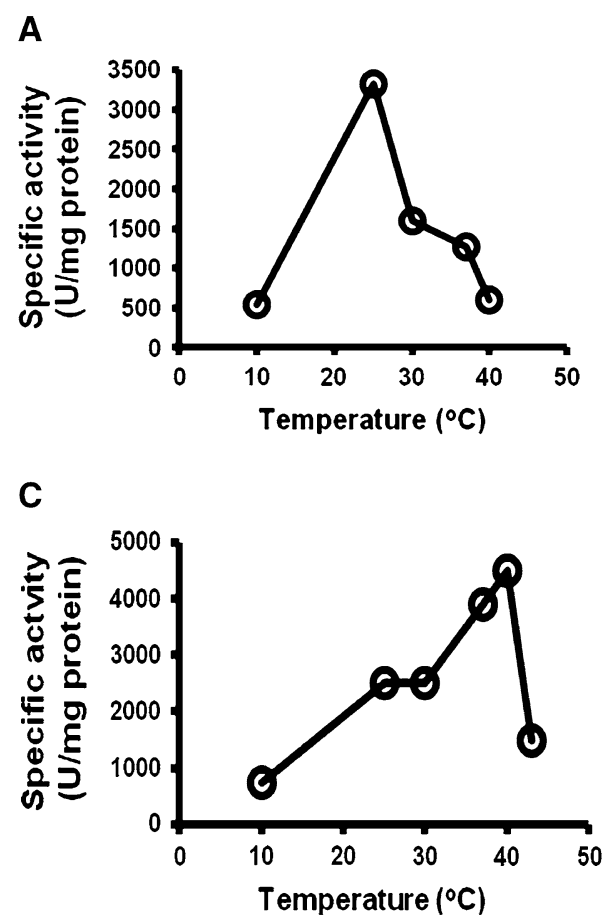
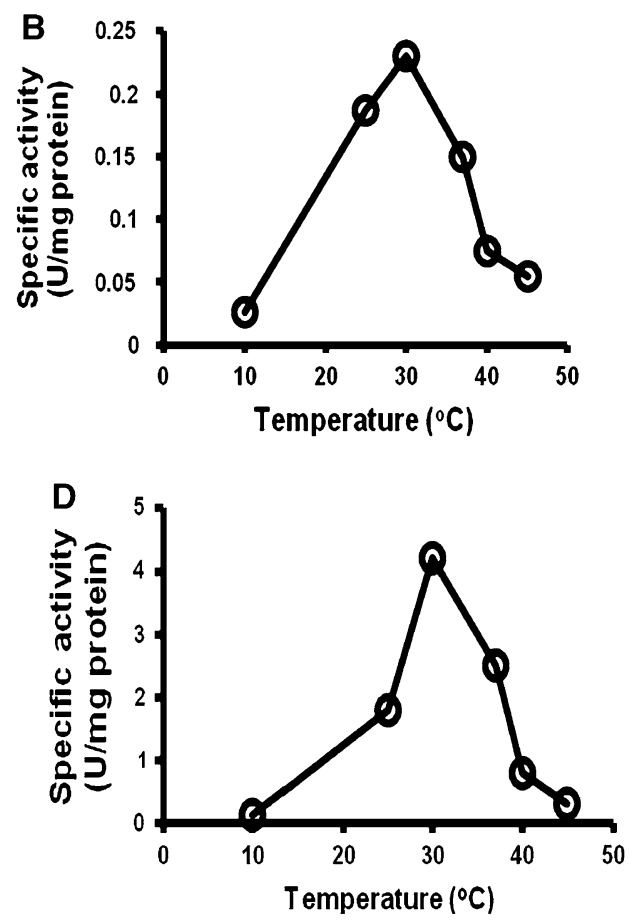

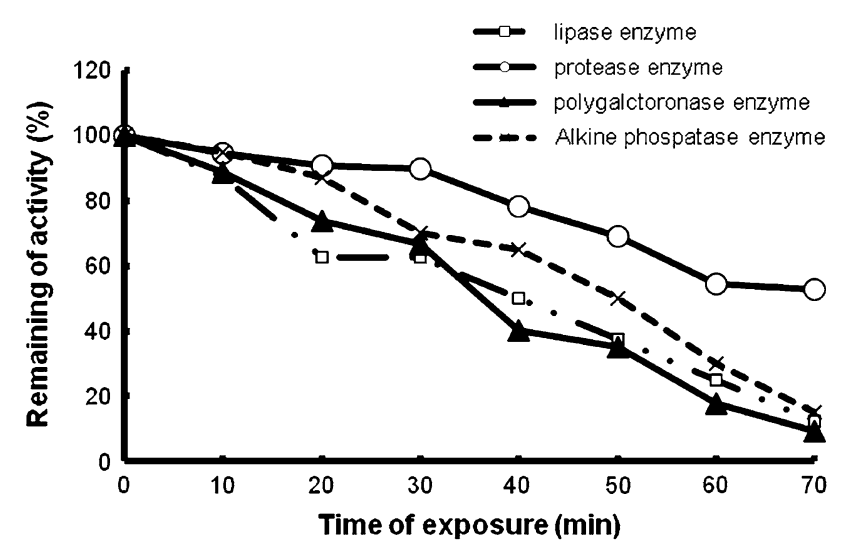

Fig. 3 Thermal stability of enzymes produced by Serratia rubidaea at $45^{\circ} \mathrm{C}$

determined by the genetic background of both the microbe and the host plant (Tyler and Triplett 2008).

Serratia rubidaea was the most prevalent bacteria recovered from naturally infected green pepper fruits in this study, representing $85 \%$ of the total. The pathogenicity test was performed on healthy green pepper fruits and red colonies were reisolated from inoculated fruits showing splotches.

The habitats of $S$. rubidaea are not perfectly known. $S$. rubidaea has been repeatedly isolated from coconuts bought in France (originating mostly from Ivory Coast) and in California (Grimont et al. 1981). It has been isolated from coconuts and from vegetable salads, but it has not been reported from water, insects, small mammals, or animal territories (Grimont and Grimont 1991).
Serratia species are important in plant and food microbiology because not only are they involved in food spoilage but also they are opportunistic pathogens that can cause various diseases in humans, animals, and plants. They have been isolated from coconuts and vegetable salads, but not reported from water, insects, small mammals, or animal territories (Grimont and Grimont 1991).

The virulence of the plant pathogen $S$. rubidaea is dependent on the production and secretion of a large variety of plant cell wall-degrading enzymes and membrane constituents, including polygalacturonase, lipase, protease and alkaline phosphatase. The activity of the type of induced enzyme may be influenced by environmental factors. Their activity may be significantly diminished or destroyed by a variety of physical or chemical agents resulting in a loss of the functions performed by the enzymes. A characteristic feature of many phytopathogenic organisms is their ability to produce an array of enzymes capable of degrading the complex polysaccharides of the plant cell wall and membrane constituents. These enzymes are usually produced inductively and are extracellular, highly stable and present in infected host tissue (Bateman and Basham 1976). A major virulence factor in onion pathogenicity is the presence of a polygalacturonase enzyme involved in tissue maceration that is encoded by the plasmid-borne pehA gene (Gonzalez et al. 1997). In conclusion, these bacteria isolated in current study may be pathogenic for humans and could be a threat to human health in food.

Acknowledgments I thank the Nora Bent AbdulRahman University for sustained support and encouragement. 
Conflict of interest The author declares that they have no conflict of interest.

Open Access This article is distributed under the terms of the Creative Commons Attribution License which permits any use, distribution, and reproduction in any medium, provided the original author(s) and the source are credited.

\section{References}

Abd-Alla MH (1994) Phosphatases and the utilization of organic phosphorus by Rhizobium leguminosarum biovar viceae phosphatases. Lett Appl Microbiol 18:294-296

Abd-Alla MH, Bashandy SR, Schnell S, Ratering S (2011) Isolation and characterization of Serratia rubidaea from dark brown spots of tomato fruits. Phytoparasitica 39(2):175-183

Al-Anazi KA, Al-Jasser AM, Al-Zahrani HA, Chaudhri N, AlMohareb FI (2008) Klebsiella oxytoca bacteremia causing septic shock in recipients of hematopoietic stem cell transplant: two case reports. Cases J 1:160-164

Baharum SN, Salleh AB, Razak CNA, Basri M et al (2003) Organic solvent tolerant lipase by Pseudomonas sp. strain S5: stability of enzyme in organic solvent and physical factors affecting its production. Ann Microbiol 53:75-83

Bateman DF, Basham HG (1976) Degradation of plant cell walls and membranes by microbial enzymes. Physiol Plant Pathol 4:316-335

Berg G, Eberl L, Hartmann A (2005) The rhizosphere as a reservoir for opportunistic human pathogenic bacteria. Environ Microbiol $7: 1673-1685$

Blostein J (1991) An outbreak of Salmonella javiana associated with consumption of watermelon. J Environ Health 56:29-31

Brenner DJ, Krieg NR, Staley JT, Garrity GM (2005) Bergey's manual of systematic bacteriology (The Proteobacteria) part B (The Gammaproteobacteria), vol 2. Springer, New York, pp 633-638

Bruhn CM (1995) Consumer attitudes and market response to irradiated food. J Food Prot 58:175-181

Cappellini RA, Ceponis MJ, Wells JM, Lightner GW (1984) Disorders in potato shipments to the New York market, 1972-1980. Plant Dis 68:1018-1020

Ceponis MJ, Cappellini RA, Lightner GW (1985) Disorders in crisphead lettuce shipments to the New York market, 1972-1984. Plant Dis 69:1016-1020

Ceponis MJ, Cappellini PA, Lightner GW (1986) Disorders in tomato shipments to the New York market, 1972-1984. Plant Dis 70:261-265

Ceponis MJ, Cappellini RA, Lightner GW (1987) Disorders in fresh pepper shipments to the New York market, 1972-1984. Plant Dis 71:380-382

Chakraborty R, Srinivasan M (1993) Production of a thermostable alkaline protease by a new Pseudomonas sp. by solid substrate fermentation. Microbiol Biotechnol 8:7-16

Cotter JL, Fader RC, Lilley C, Herndon DN (1985) Chemical parameters, antimicrobial activities, and tissue toxicity of 0.1 and $0.5 \%$ sodium hypochlorite solutions. Am Soc Microbiol 28:118-122

Drancourt M, Bollet C, Carlioz A, Martelin R, Gayral JP, Raoult D (2000) 16S Ribosomal DNA sequence Analysis of a large collection of environmental and clinical unidentifiable bacterial isolates. Clin Microbiol 38:3623-3630

Fadıloğlu S, SÖylemez Z (1997) Kinetics of lipase-catalyzed hydrolysis of olive oil. Food Res Int 30:171-175
Farmer JJ III, Davis BR, Hickman-Brenner FW, McWhorter A, Huntley GP et al (1985) Biochemical identification of new species and biogroups of Enterobacteriaceae isolated from clinical specimens. Clin Microbiol 21:46-76

Garcia-Martınez J, Bescos I, Rodrı' guez-Sala JJ, Valera FR (2001) RISSC: a novel database for ribosomal 16S-23S RNA gene spacer regions. Nucleic Acids Res 29:178-180

Gomes I, Saha RK, Mohiuddin G, Hoq MM (1992) Isolation and characterization of cellulase-free pectinolytic and hemicellulolytic thermophilie fungus. World J Microbiol Biotechnol 8:589-592

Gonzalez CF, Pettit EA, Valadez VA, Provin E (1997) Mobilization, cloning, and sequence determination of a plasmid-encoded polygalacturonase from a phytopathogenic Burkholderia (Pseudomonas) cepacia. Mol Plant-Microbe Interact 10:840-851

Gorkiewicz G (2009) Nosocomial and antibiotic-associated diarrhoea caused by organisms other than Clostridium difficile. Int $\mathrm{J}$ Antimicrob Agents 33:37-41

Grimont F, Grimont PAD (1991) The genus Serratia. In: Balows A, Trüper HG, Dworkin M, Harder W, Schleifer KH (eds) The prokaryotes, Springer, Verlag pp. 2822-2848

Grimont PAD, Grimont F, Starr MP (1981) Serratia species isolated from plants. Curr Microbiol 5:317-322

Guo X, Chen J, Brackett RE, Beuchat LR (2001) Survival of Salmonellae on and in tomato plants from the time of inoculation at flowering and early stages of fruit development through fruit ripening. Appl Environ Microbiol 67:4760-4764

Högenauer C, Langner C, Beubler E, Lippe IT, Schicho R et al (2006) Klebsiella oxytoca as a causative organism of antibiotic-associated hemorrhagic colitis. N Engl J Med 355:2418-2426

Kroupitski Y, Golberg D, Belausov E, Pinto R, Swartzberg D et al (2009) Internalization of Salmonella enterica in leaves is induced by light and involves chemotaxis and penetration through open stomata. Appl Environ Microbiol 75:6076-6086

Lane DJ (1991) 16S/23S rRNA sequencing, Nucleic acid techniques in bacteria systematics. In: Stackebrandt E, Goodfellow M (eds) John Wiley, New York pp 115-175

Lund BM (1983) Bacterial spoilage. In: Dennis C (ed) Postharvest pathology of fruits and vegetables. Academic Press, London, pp 219-257

Ohara-Nemoto Y, Sasaki M, Kaneko M, Nemoto T, Ota M (1994) Cysteine protease activity of streptococcal pyrogenic exotoxin B. J Clin Microbiol 40:930-936

Roever De (1998) Microbiological safety evaluations and recommendations on fresh produce. Food Control 6:321-347

Samish Z, Etinger-Tulczynska R, Bick M (1962) The microflora within the tissue of fruits and vegetables. Food Sci 28:259-266

Sanger F, Nicklen S, Coulson A (1977) DNA sequencing with chainterminating inhibitors. Proc Natl Acad Sci USA 74:5463-5467

Schaad NW (1988) Laboratory guide for identification of plant pathogenic bacteria. APS Press, St. Paul 1-15

Snowdon AL (ed) (1990) A color atlas of post- harvest diseases of fruits and vegetables. Vol 2 Vegetables. CRC Press, Boca Raton

Stapp C (1940) Bacterium rubidaeum nov. spec. Zentratbl Bakteriol Abt 102:251-261

Tyler HL, Triplett EW (2008) Plants as a habitat for beneficial and/or human pathogenic bacteria. Annu Rev Phytopathol 46:53-73

Wei CI, Huang TS, Kim JM, Lin WF et al (1995) Growth and survival of Salmonella Montevideo on tomatoes and disinfection with chlorinated water. Food Prot 58:829-836

Wright C, Kominos SD, Yee RB (1976) Enterobacteriaceae and Pseudomonas aeruginosa recovered from vegetable salads. Appl Environ Microbiol 31:453-454

Zunino P, Geymonat L, Allen AG, Legnani-Fajardo C, Maskell DJ (2000) Virulence of a Proteus mirabilis ATF isogenic mutant is not impaired in a mouse model of ascending urinary tract infection. FEMS Immunol Med Microbiol 29:137-143 